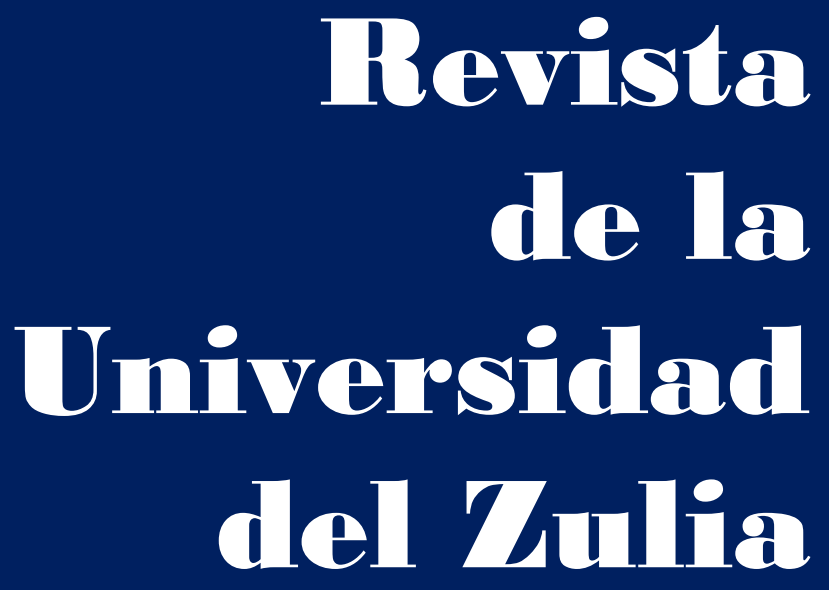

Fundada en 1947

por el Dr. Jesús Enrique Lossada

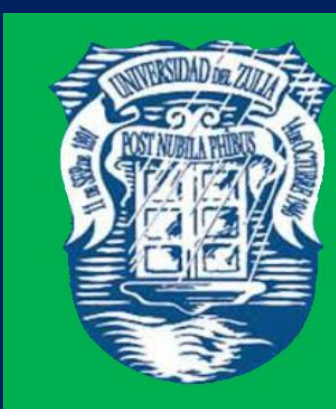

Ciencias del

Agred

Ingemieria

y Teenología
Añต 12 No 32

Enero - Abril 2021

Tercera Época

Maracailbo-Venezuela 


\title{
Thematic analysis on a model of implementation of open and technological banking in commercial banks in Iran
}

\author{
Mohammad Bagher Arayesh * \\ Mostafa Rezaeirad ** \\ Mohammad Aidi *** \\ Tohfeh Ghobadi Lamoki****
}

\begin{abstract}
The purpose of this study was the thematic analysis on a model of implementation of open and technological banking in commercial banks in Iran. It is an applied study; in terms of method, qualitative; And in terms of research philosophy, it is a kind of interpretive research. To analyze the data from the semi-structured interviews, a thematic analysis was used. The population of this study included 20 knowledgeable people (experts in banking and university professors in the field of open banking, as well as appropriate texts for the extraction of indicators). In this investigation a snowball approach was used to select samples. As a standard for the end of sampling, the thematic saturation method is used. The topics were obtained using the two sources of theoretical literature and semi-structured interviews. The result of the qualitative data analysis led to the identification of 25 basic issues, 6 organizational issues and finally 4 contextual issues including productivity and digital governance in the shadow of knowledge, alliances with competing partners, customer experience management, digital strategic management of economic and customer management, and reform of banking processes, all presented in the form of a model. Finally, suggestions were made in this area based on the results.
\end{abstract}

KEY WORDS: Open Banking, Thematic Analysis, Implementation, Commercial Banks of Iran

${ }^{*}$ Ph.D Student of Business Management, Hamedan Branch, Islamic Azad University, Hamedan, Iran. E-mail: arayesh.b@gmail.com

**Assistant, professor, Faculty of Humanities, University of Hamedan, Hamedan, Iran. E-mail: m.rezaeirad@basu.ac.ir

${ }^{* * *}$ Assistant, professor, Faculty of Humanities, University of Ilam, Ilam, Iran. E-mail: M.aidi@ilam.ac.ir

${ }^{* * * *}$ Assistant, professor, Faculty of Humanities, Hamedan Branch, Islamic Azad University, Hamedan, Iran. E-mail: t_ghobadi@yahoo.com

Recibido: 10/09/2020

Aceptado: 05/11/2020 


\section{Análisis temático sobre un modelo de implementación de banca abierta y tecnológica en bancos comerciales de Irán}

RESUMEN

El propósito de este estudio fue el análisis temático sobre un modelo de implementación de banca abierta y tecnológica en los bancos comerciales de Irán. Es un estudio aplicado; en términos de método, cualitativo; y en términos de filosofía de la investigación, es un tipo de investigación de interpretación. Para analizar los datos de las entrevistas semiestructuradas se ha utilizado un análisis temático. La población de este estudio incluyó a 20 personas conocedoras (expertos en banca y profesores universitarios en el campo de la temática de banca abierta, así como textos apropiados para la extracción de indicadores). En esta investigación se utilizó un enfoque de bola de nieve para seleccionar muestras. Como estándar para el final de muestreo, se utiliza el método de saturación temática. Los temas se obtuvieron utilizando las dos fuentes de literatura teórica y entrevistas semiestructuradas. El resultado del análisis de datos cualitativos llevó a identificar 25 temas básicos, 6 temas organizativos y finalmente 4 temas contextuales incluyendo productividad y gobernanza digital a la sombra del conocimiento, alianzas con socios competidores, gestión de la experiencia de los clientes, gestión estratégica digital de la gestión económica y de clientes, y reforma de los procesos bancarios, todo ello presentado en forma de modelo. Finalmente, se hicieron sugerencias en esta área basado en los resultados.

PALABRAS CLAVE: Apertura bancaria, Análisis Temático, Implementación, Bancos Comerciales de Irán.

\section{Introduction}

The current business environment is constantly experiencing, influenced by factors such as expanding science and technology, increasing competition and globalization, new evolution (Asadollah, Sanavifard \& Hamidizadeh, 2019; Dargahi \& Tahriri, 2020). In this environment, the survival condition of any organization will be to adapt to rapidly changing technology and to accept the demands of sustainability in an unstable competitive environment. Over the years, banks have always been leading the way in providing new services but, the banking business environment is changing dramatically and traditional banking structures are collapsing (Berger, Molyneux \& Wilson, 2012). shortly, emerging technologies, new regulations, innovations and changing customer expectations will fundamentally change the banking industry (Eckenrode, 2017). Traditional banking systems, bureaucratic and even electronic banking systems not only do they lack 
REVISTA DE LA UNIVERSIDAD DEL ZULIA. 3a época. Año 12 Nº 32, 2021

Mohammad Bagher Arayesh et al. /// Thematic analysis on a model of implementation of open ... 414-443

DOI: http://dx.doi.org/10.46925//rdluz.32.25

competition (Cajetan \& Ezepue, 2018) but also, have no impact on the competitive advantage, attraction and, retention of new customers. Banks are therefore not only at risk of losing direct customer relationships, but may lose many of their services and consequently their customers as well. These trends and the emergence of open banking are a major change for banks and the financial system(OECD, 2020). Oracle financial services (2018) believes that the most important challenges for Asian banks are recruiting and retraining talent (38\%), attracting new customers (34\%) and market newcomers (25\%), and their most important investment priorities include promotion. Customer service (51\%), research, development and innovation (40\%) and new product development (34\%).

According to a McKinsey company report, a range of competitors such as fin techs and rival banks with emerging business models are emerging in the financial services industry. Estimates show that more than 60 percent of profits and 40 percent of traditional and micro-banking will decrease with the entry of new actors into the banking and financial ecosystem (Deloitte, 2014). To survive in this ecosystem, banks will need to recreate their current business models, continuous innovation, agility, and optimize structures to achieve sustainable competitive advantage (OECD, 2020). Nowadays, the customer definition of a good bank is a bank that does not need to go to a branch to provide more access to remote banking services. At present, one cannot expect a bank to meet all the financial services of a technology leader alone given the staggering growth of technology. The notion that the bank should meet all the micro and macro needs of its specific customers in general, has become obsolete and customers have different expectations. Despite the many communication channels that closed banking offers to its customers, Not only have customers not been saturated, but it has increased their expectation to receive services tailored to the state of the art (Asadollah et al., 2019). It is here that the need for open banking is felt to converge banks and startups (Adrian \& Mancini-Griffoli, 2019).

According to the Accenture Institute, about 20 percent of banks have invested in open banking by 2017, and 77 percent of banks will do so by the end of 2019 (Accenture, 2018). Open Banking, also known as Software Development Interface Banking and Digital Banking, is a new paradigm that aims to interact more with customers, personalize and meet each customer's specific needs, provide potential value added for monetary 
REVISTA DE LA UNIVERSIDAD DEL ZULIA. 3a época. Año 12 Nº 32, 2021

Mohammad Bagher Arayesh et al. /// Thematic analysis on a model of implementation of open ... 414-443

DOI: http://dx.doi.org/10.46925//rdluz.32.25

institutions and banks, and monopolize Bank production is fast becoming popular in the world of banking (Deloitte, 2015), which has not been widely considered in Iran so far. Open banking means digitizing all the activities of traditional banking programs that have previously only been offered to customers in the physical branch (Ramdani, Rothwell and Boukrami, 2020). Open banking does not mean online or offline banking. In this type of banking, the physical branches of banks will not be removed, but, they will shift from the current axial transaction to the axial consultation (OECD, 2020). Despite Iran's great potential for Application software development, many applications still require direct access to banking services. Open Banking provides this platform for software developers to implement new and creative ideas through access to banking services (Brodsky $\&$ Oakes, 2017).

This new approach also allows banks to share their customers' financial information with businesses and companies with the required standards (Ramdani er al., 2020). In Iran, this process has just begun and fortunately, the Central Bank has taken the first steps to comply with these conditions. It is to be hoped that this process will continue expeditiously and deeply to make the Iranian banking system a more welcoming industry for its citizens. With the advent of new technologies, in addition to evolving banking models, new businesses are emerging in the field of financial technology that will naturally target a portion of the financial and banking services market. Accordingly, future bank growth will be possible only through Strategic partnership and integration (with fin techs or other banks) as well as growth through innovative investments (artificial intelligence and artificial cognition opportunities, blockchains, robotic automation and improve cybersecurity (OECD, 2020).

The fact is that there are almost no issues with designing and implementing open banking in Iran, and given that there has not been much focus on the open banking process modeling in domestic and foreign sources and practically, new applied knowledge in Iran and the world is considered, thus, there is considerable theoretical development capacity in this area. Therefore, the main issue of this study is to present a theoretical model of open banking implementation through thematic analysis method. Nowadays, due to the digitalization movement of the world's leading banks, there is a need to develop an application model for implementing an open banking model that reflects the unique 
REVISTA DE LA UNIVERSIDAD DEL ZULIA. 3época. Año $12 \mathrm{~N}^{\circ}$ 32, 2021

Mohammad Bagher Arayesh et al. /// Thematic analysis on a model of implementation of open ... 414-443

DOI: http://dx.doi.org/10.46925//rdluz.32.25

features of Iranian commercial banks. Accordingly, the main objective of this study is to present thematic analysis on a model of implementation of open and technological banking in commercial banks in Iran

\section{Literature review}

\subsection{Theoretical background}

Various evidence shows that customers and companies can do a better transaction in open banking. Customers tend to stay with the same banking service provider for long periods, even in the presence of more competitive offers (Delloite, 2015). In the face of this complexity, many clients base their decisions on experience-based rules or shortcuts - such as following what their colleagues do and choosing a well-known institution. In some cases, such decision processes can lead to a reasonable outcome for the customer. In others, they can have a significant and detrimental effect on individuals' long-term financial consequences (Asadollah et al., 2019). Open banking can lead to the development of new financial products and services for specific customer groups. Increase data sharing gives opportunities to financial service providers to access data on disadvantaged customers (Reynolds, 2017), Enabling them to gain a fuller picture of their customers' financial situation and the development of products and services tailored to their needs (Accenture, 2018). In many cases, open banking is a simple concept, especially as it enables its customers to easily and securely share their banking data with trusted groups (OECD, 2020). Customer-centered open banking, promoting competitiveness, encouraging innovation, efficient and fair open banking and providing competitive approaches are the most important open banking capabilities (Ramdani et al., 2020).

Over the past years, traditional banks have defined specific products and services for customers and due to the limited selection options, customers had to go to banks and get bank-defined services (Brodsky \& Oakes, 2017). In other words, banks were market leaders, and customers were following them (Reynolds, 2017). With the increasing number of banks, customer preference was no longer limited to the existence or absence of service. They could choose between different banks. In these circumstances, banks have focused on how to offer their services to customers. Any bank that offered more value to customers was more likely to be accepted by customers (Hallsworth et al., 2019). Therefore, it is clear 
REVISTA DE LA UNIVERSIDAD DEL ZULIA. 3a época. Año 12 Nº 32, 2021

Mohammad Bagher Arayesh et al. /// Thematic analysis on a model of implementation of open ... 414-443

DOI: http://dx.doi.org/10.46925//rdluz.32.25

that in modern banking, creating a unique and excellent experience for receiving services (banking and non-banking) is the most important goal (Deloitte, 2014). With this approach, on the one hand, bank customers meet their expectations and, on the other hand, more and more sustainable sources of revenue will be created for value-added banks (OECD, 2020). Entering this field occurs when the bank changes its view of the customer market, competition and service delivery (Owen \& Pereira, 2018).

One of the most fundamental strategies resulting from Changing the Look of the Banking System is moving towards an open banking industry (Hallsworth er al., 2019). Generally in open banking, the value chain of financial services is defined at three levels of products, interface, and services. At the first level, the products are developed. These products are converted to services using user interfaces (Reynolds, 2017). Open Banking redefines the development and distribution of its products through the provision of new technologies, legislation and the development of new technologies (OECD, 2020).

New open-source combinations of services, capabilities, and data can be created if new programming interfaces are made available to third party actors with personalization capabilities. Also, third parties can integrate functional capabilities, banking data and products with their services and facilitate new services and products and provide new products and services (Brodsky \& Oakes, 2017). There are two main ways to create open banking. One way is for banks to be seen as markets and the other is that banks are seen as platforms and change roles (Omarini, 2018). If the bank is seen as a market, open banking is expected to come alongside the bank's core services! and allows third-party partners to access parts of customer information, provide them with semi-open access or banking applications. By doing this, they can produce products according to banking services. But it should be noted that defining open source programming interfaces that provide easy access and good integration of products is the main challenge of this type of open banking (Deloitte, 2015).

When the bank is seen as a platform, the bank creates a framework of open programming interfaces and makes them available to all third parties interested in designing new products. In this case, the bank will have limited control over the products and tools created (Euro bank association, 2017). In this type of open banking, the depth of innovation and third-party space will be greater than open banking as a market (Omarini, 
REVISTA DE LA UNIVERSIDAD DEL ZULIA. 3a época. Año 12 Nº 32, 2021

Mohammad Bagher Arayesh et al. /// Thematic analysis on a model of implementation of open ... 414-443

DOI: http://dx.doi.org/10.46925//rdluz.32.25

2018). At the same time, this type of open banking is closer to the requirements of the role of customer information providers in the European Payment Services Guide (Chaudhry et al., 2016).

Open Banking as a platform means that banks operating in this field, by redefining the scope of their business are trying to attract innovation from outside the banks. In open systems, the software is not owned and managed by a single company. It supported by a community or larger group of stakeholders such as small companies, individuals, large corporations or universities (OECD, 2020). This form of collaboration can be accompanied by more and faster innovations and increased efficiency (Ramdani et al., 2020). It is believed that the most important trend of banking in the future is the transformation of banks into platforms. In this situation, both banks and startups can move towards becoming a platform through strategic joint action. Depending on the strategy selected for the bank and the type of service, open planning interfaces can be defined at different levels (Deloitte, 2015). On the path of open banking development, banks choose different approaches based on their strategies. These approaches can be selected by answering two key questions that show what role the bank intends to play in the financial value chain: Who develops banking products? Who delivers banking products to customers? In answer to these two questions, four types of banks can be identified (OECD, 2020؛ Deloitte, 2020).

Core Banks: This approach is similar to traditional banking. In these circumstances, the Bank directly performs activities such as product development, distribution, and delivery to customers. There are no third parties in these situations.

Distributor banks: In this approach, the bank provides a product development space for third party actors, and assumes the delivery of products to customers. In this framework, banks are expanding their digital market and provide good services to business partners and third parties, thus, they have the role of a distributor. Today, fin techs play a distributive role in the payment industry because they categorize and distribute services created by banks and other payment service providers.

Producer Banks: In this approach, the bank's focus is on product and service development and Product Distribution up to the delivery stage to the customer is the role that business partners and third parties will play. Suggest to the customer in this approach 
REVISTA DE LA UNIVERSIDAD DEL ZULIA. 3a época. Año 12 Nº 32, 2021

Mohammad Bagher Arayesh et al. /// Thematic analysis on a model of implementation of open ... 414-443

DOI: http://dx.doi.org/10.46925//rdluz.32.25

is done by at least 2 groups. The bank produces services, and outsiders, who can be Fin Tech, provide services to customers.

Platform banks: This approach is the ultimate in open banking. In this approach, the bank provides the necessary framework for third party activity across all value chains of financial services. Here the platform is one of the types of business models and it's different from the Interpretation of the platform in the software world. In this approach, banks can offer client matching, security and customer recognition capabilities as a platform.

\subsection{Experimental background}

Camerinelli (2017) states in his research that managing funds, applying for online credit card, virtual prepaid credit card for secured payments, mobile loan application, SMSbased payments, mobile payment in stores and taxis, personalized products and services and the existence of a remote financial advisor are the most important user expectations of open banking. According to a research report by Mckinsey \& Company (2017), Banking in any time, any place, with any device, Analysis of clients' personal experience, customercentric, immediate fulfillment of needs, acceptance of open banking power, cost-effective, less operational risk, constant updating, market leadership, scalability and cloud infrastructure implementation, customer experience platform, centralized applications, channels, branches and call center, bank model(Micro, corporate, investment), devices (tablet, cell phone, ...) were the most important requirement of banking system to be digitalized. In the report of Fingleton (2019), is noted that the implementation of openbank banking takes place in 6 stages including:

a) Develop standards, b) Implement standards, c) Engage and connect with TPPS, d) TPPs develop propositions, e) TPPs launch and refine propositions in market and f) Evaluate success.

In a study done by Hallsworth er al (2019), is introduced five ecosystem requirements for successful open banking that are included: APIs, Enabling assets, Use cases, Killer apps and Partnerships. Martin hearing (2019), believes that before implementing a new model, it is necessary to pay attention to the following four elements: 
REVISTA DE LA UNIVERSIDAD DEL ZULIA. 3a época. Año 12 Nº 32, 2021

Mohammad Bagher Arayesh et al. /// Thematic analysis on a model of implementation of open ... 414-443

DOI: http://dx.doi.org/10.46925//rdluz.32.25

a) Unified Strategy, b) Collaborative Mindset, c) Open Culture, d) Diligent Compliance

According to a research report by (Lipton, Shrier \& Pentland, 2016), is noted that the most key requirements for a digital bank from the viewpoint of bank, investor and consumer is introduced:

-from Customers' Perspective: holistic customizable, biometric, mobile-first, end to end digital, electronic credit card, ambient channel management.

-from bank' Perspective: full-stack business model, artificial intelligence-enabled, security and discretion, novel database design, advanced data analytics, and digital payments.

-from investor' Perspective: digital sales and banking products, multichannel, rob advisor, digital financial planner, SME upside, smart big data, a digital wallet.

In the research of Barquin, Vinayamak \& Heidi (2015), the key aspects of open banking are mentioned. The four features of quality, essential services, the power of financial products and services, brand reputation and customer experience are particularly important in open banking. Simplicity and security are also important aspects of open banking that increase customer satisfaction. In the research done by Deloitte (2015), factors such as social networks, consumer protection, products, digital investment, internet, Fintechs, block Chin technology and biometric technology are the most important factors affecting the customer and bank on the digitalization highway. In a study done by Deloitte (2019) entitled "creating an open banking Framework for Canada", the most important constraints and limitations of open banking have been reported. These include:/ new entrants, data breaches, fraud, privacy, recourse, distribution of costs.

\section{Research methodology}

This study is applied based on the purpose of research, and in terms of a philosophy of research is interpretive. The thematic analysis method was used to analyze the data from semi-structured interviews and analysis of the texts used. thematic analysis is a process for analyzing qualitative information and is used in most qualitative methods. Because, the thematic analysis method deals with the analysis of the text, then, is carried out the process of gathering information in the form of textual cycles. 
REVISTA DE LA UNIVERSIDAD DEL ZULIA. 3a época. Año 12 Nº 32, 2021

Mohammad Bagher Arayesh et al. /// Thematic analysis on a model of implementation of open ... 414-443

DOI: http://dx.doi.org/10.46925//rdluz.32.25

The researcher achieves a better understanding of the text by following the cyclic path within the text. This path will continue until it is reached an acceptable understanding of the text with the least internal contradiction. The theme states important information about research data and questions and it shows the meaning of the current pattern in the data set (Braun \& Clark, 2006).

The thematic analysis is a data reduction and analysis strategy as well as the classification, summarization, and reconstruction of qualitative data (Alhojailan, 2012). In this way, the researcher seeks to find meaningful duplicate patterns. Repeat means that at least 2 of the texts can receive a subject. Based on specific procedures at three levels, it offers basic themes (codes and key points in the text), organizing themes (themes derived from the composition and summary of the basic themes) and inclusive themes (higher themes include the principles governing the text as a whole) in which, the themes are put together concerning each other (Attride-Stirling, 2001).

To achieve the objectives of the research, the qualitative process was carried out in two stages. In the first step, due to the multitude of articles related to digital banking and to select appropriate articles to extract effective indicators, was used meta-analysis with seven-step approach. Where qualitative research was combined, their similarities and differences were compared, their findings were translated into one another, finally, a new interpretation of their collection was obtained. The statistical population in this section included all articles published in the domestic journals databases (Sid, Magiran, Noormags) and valid international databases (Sciencedirect, Proquest, Springer, Emerald, Wiley, Sage) from 2014 to 2019. In total, 43 articles were identified. Criteria such as keyword allocation, subject area, access level, and screening for inclusion or exclusion of articles were used to obtain the best articles to enter the hyperbolic process. From the total number of articles obtained, 16 articles, which had very good and excellent quality in the evaluation table, were evaluated as the sample and for data extraction.

Semi-structured interview with an exploratory approach in the second stage of qualitative research was used to extract complementary indicators related to open banking implementation, for this purpose, semi-structured interviews were conducted with 13 managers of commercial banks of Saman, Iran Zamin, Ayandeh, Mellat, City Bank, Melli and Tejarat, 7 university professors who familiar with banking issues. 
REVISTA DE LA UNIVERSIDAD DEL ZULIA. 3a época. Año 12 Nº 32, 2021

Mohammad Bagher Arayesh et al. /// Thematic analysis on a model of implementation of open ... 414-443

DOI: http://dx.doi.org/10.46925//rdluz.32.25

At the beginning of the interview, the purpose of the study was to emphasize that the interviews will be used for research purposes only and that the identities of the individuals will not be mentioned in the research reports. for selection of the sample, nonprobable purposive judgment sampling with a snowball sampling approach was used. Select samples continued until the adequacy and theoretical saturation stage. Twenty people were interviewed in this study, which was repeated in the information received from the 17th interview, but to ensure data adequacy continued until interview 23 thematic analysis encompasses a wide range of methods and techniques (template themes, thematic Matrix, thematic network, and comparative analysis).

In this study, the thematic network method was identified as a suitable method for thematic analysis. What the themes network offers is a web-like map as the organizing principle and method of display. Thematic network systematizes the basic, organizing inclusive themes, based on the specific process. It is important to note that, the thematic network is not a procedure for preparing the analysis or delivering the final results, but rather a technique for breaking the text and finding meaningful and salient points within the text. Figure 1 illustrates the structure of a thematic network.

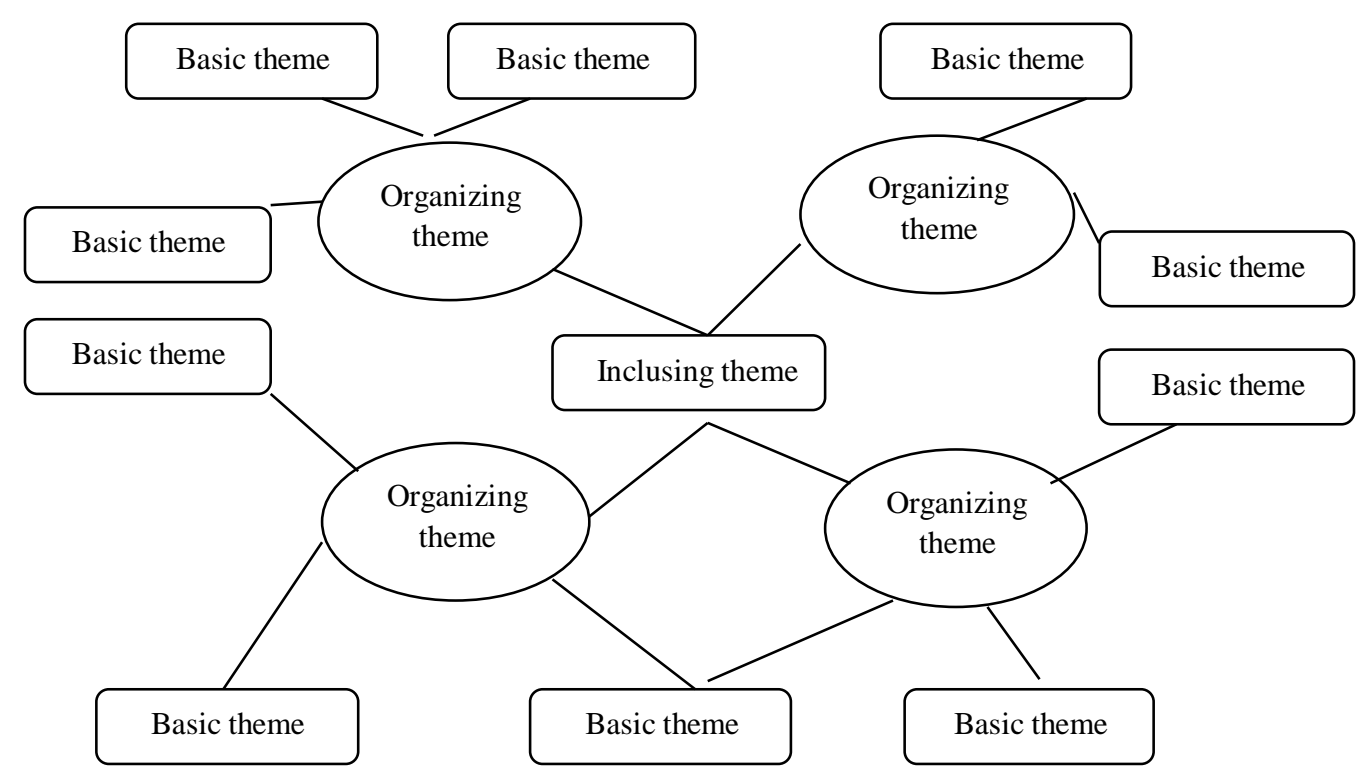

Figure 1 . The structure of a thematic network Source: (Vaezi et al., 2018: 23) 
REVISTA DE LA UNIVERSIDAD DEL ZULIA. 3época. Año 12 N 32, 2021

Mohammad Bagher Arayesh et al. /// Thematic analysis on a model of implementation of open ... 414-443

DOI: http://dx.doi.org/10.46925//rdluz.32.25

Tablel shows the demographic characteristics of the statistical samples.

Table 1. Demographic characteristics of research interviewees

\begin{tabular}{|c|c|c|c|c|c|c|c|}
\hline No & Educational level & age & Gender & No & Educational level & age & Gender \\
\hline 1 & PhD in Marketing & 46 & woman & 11 & $\begin{array}{l}\text { PhD in business } \\
\text { management }\end{array}$ & 60 & man \\
\hline 2 & $\mathrm{PhD}$ in IT & 50 & man & 12 & $\mathrm{PhD}$ in $\mathrm{E}$ - Comerce & 56 & man \\
\hline 3 & $\mathrm{PhD}$ in IT & 52 & man & 13 & $\begin{array}{l}\text { PhD in electronic } \\
\text { banking }\end{array}$ & 58 & man \\
\hline 4 & PhD in E-Comerce & 54 & man & 14 & MSc in marketing & 39 & woman \\
\hline 5 & MSc in IT & 38 & woman & 15 & PhD in business law & 50 & woman \\
\hline 6 & PhD in IT & 42 & woman & 16 & $\mathrm{PhD}$ in IT & 52 & man \\
\hline 7 & PhD in business management & 49 & woman & 17 & $\begin{array}{l}\text { PhD in computer } \\
\text { science }\end{array}$ & 53 & man \\
\hline 8 & PhD in electronic banking & 44 & man & 18 & $\begin{array}{l}\text { PhD in computer } \\
\text { science }\end{array}$ & 48 & man \\
\hline 9 & MSc in IT & 47 & man & 19 & $\begin{array}{c}\text { PhD in international } \\
\text { marketing }\end{array}$ & 40 & man \\
\hline 10 & PhD in international marketing & 43 & man & 20 & $\begin{array}{c}\text { PhD in electronic } \\
\text { banking }\end{array}$ & 41 & man \\
\hline
\end{tabular}

\section{Source: Research findings}

Reliability refers to the consistency of the results of the interview, the credibility and the ability of the interviewee to measure the intended goals. Validity is said to be the ability of a method to measure the purpose of the study. In the present study, the reliability of the two coders was used to calculate the reliability of the interviews. To this purpose, a university professor who was aristocratic on the research subject was asked to participate as a researcher (coder) in this research. Then, The researcher along with the research colleague coded three interviews and calculated the percentage of the intra-subject agreement as a measure of research reliability. How to calculate the percentage of intrasubject agreement is given in Formula l:

Formulal. Percentage of intergroup agreement $=\mathrm{A} \times 2 / \mathrm{B} \times 100$

That $\mathrm{A}=$ Number of agreements reached, $\mathrm{B}=$ Total number of codes 
REVISTA DE LA UNIVERSIDAD DEL ZULIA. 3a época. Año 12 Nº 32, 2021

Mohammad Bagher Arayesh et al. /// Thematic analysis on a model of implementation of open ... 414-443

DOI: http://dx.doi.org/10.46925//rdluz.32.25

To extract the amount and the number of agreements, a questionnaire containing themes, along with open coding samples, was provided to the research participants and the degree of agreement was questioned through the choice questions of high, medium, and low concordance. If the participant chooses the low or medium option, it means disagreement, and if the participant chooses the high option, it means an agreement (Vaezi, Chekin\& Aslipour, 2018). Regarding the main research question, which is the model for implementing open banking in Iranian commercial banks? It was considered as the main question of the interviews.

Table 2. Calculation of reliability between two coders

\begin{tabular}{ccccc}
\hline No & $\begin{array}{c}\text { Interview } \\
\text { code }\end{array}$ & $\begin{array}{c}\text { Number of } \\
\text { codes }\end{array}$ & $\begin{array}{c}\text { Number of } \\
\text { Agreements }\end{array}$ & $\begin{array}{c}\text { Coefficient of } \\
\text { agreement }\end{array}$ \\
l & Il & 21 & 8 &.$/ 86$ \\
2 & I2 & 26 & 11 &.$/ 85$ \\
3 & I3 & 22 & 8 &.$/ 73$ \\
& Total & 69 & 28 &.$/ 81$ \\
\hline
\end{tabular}

Source: Research findings

As be seen in Table 2, the reliability between the two coders for the interviews was /81. Thus, it can be argued that the reliability of the interview analysis is appropriate. The usual size of acceptable reliability coefficient is 80 to 100 percent for most research and research with a reliability coefficient of less than $70 \%$ will have difficulty interpreting their achievements and replicating research (Vaezi et al., 2018).

\section{Results and discussion}

In the first step, the researcher recorded the interviews by the ethical principles of qualitative research and with the full consent of the interviewees first, the first interview was translated precisely into text, and the coding was done paragraph by paragraph. Key points in the context of interviews were outlined about open banking implementation, and after the initial coding, it continued until the level of determination of basic themes. This 
REVISTA DE LA UNIVERSIDAD DEL ZULIA. 3a época. Año 12 Nº 32, 2021

Mohammad Bagher Arayesh et al. /// Thematic analysis on a model of implementation of open ... 414-443

DOI: http://dx.doi.org/10.46925//rdluz.32.25

process was applied until the 17th interview and theoretical saturation. At this stage were extracted 187 original codes from the interviews with more conceptual power. In the second step, 25 basic themes were extracted from the 60 conceptual codes. In the threestep, the basic themes with the most semantic and conceptual affinities were put together, and 6 organizer themes were extracted from them. organizing themes are the answer to the research questions extracted from qualitative data. In this study, a total of 6 organizing themes were identified among the 25 basic themes. Table 3 shows Summary results of organizing themes from basic themes.

Table 3. Summary results of organizing themes from basic themes

\begin{tabular}{|c|c|c|}
\hline Conceptual code & basic themes & Organizing code \\
\hline The quality of banking operatic & \multirow{6}{*}{$\begin{array}{l}\text { Banking flexibility and } \\
\text { compatibility }\end{array}$} & \multirow{16}{*}{$\begin{array}{l}\text { Economic Management and } \\
\text { Banking Process Reform }\end{array}$} \\
\hline Banking economic criteria & & \\
\hline $\begin{array}{c}\text { changing structure and } \\
\text { downsizing }\end{array}$ & & \\
\hline banking system Integration & & \\
\hline User store integration & & \\
\hline $\begin{array}{c}\text { The power of attracting } \\
\text { stakeholders and new } \\
\text { technologies }\end{array}$ & & \\
\hline Culturalize and education & \multirow[t]{2}{*}{ Participatory culture } & \\
\hline Third party on boarding & & \\
\hline Managing key activities & \multirow{3}{*}{$\begin{array}{l}\text { Managing payment } \\
\text { channels }\end{array}$} & \\
\hline Payment channels & & \\
\hline Payments and trade & & \\
\hline Risk management & \multirow[t]{2}{*}{ Risk management } & \\
\hline Reduce risk and uncertainty & & \\
\hline Cost efficiency & \multirow{3}{*}{ Cost-benefit evaluation } & \\
\hline Income streams & & \\
\hline Cost streams & & \\
\hline Outsourcing activities & & \\
\hline
\end{tabular}


REVISTA DE LA UNIVERSIDAD DEL ZULIA. 3época. Año $12 \mathrm{~N}^{\circ}$ 32, 2021

Mohammad Bagher Arayesh et al. /// Thematic analysis on a model of implementation of open ... 414-443

DOI: http://dx.doi.org/10.46925//rdluz.32.25

\begin{tabular}{|c|c|c|}
\hline $\begin{array}{l}\text { flexibility of organizational } \\
\text { platform }\end{array}$ & \multirow[t]{4}{*}{ Activity framing } & \multirow{14}{*}{$\begin{array}{c}\text { Technical-legal compatibility } \\
\text { based on market and } \\
\text { technology optimization } \\
\text { activities }\end{array}$} \\
\hline $\begin{array}{l}\text { Architecture management and } \\
\text { API monitoring }\end{array}$ & & \\
\hline API specification & & \\
\hline Motivation and loyalty programs & & \\
\hline $\begin{array}{l}\text { Regulatory and legal } \\
\text { infrastructure }\end{array}$ & \multirow{5}{*}{ Legal requirements } & \\
\hline $\begin{array}{l}\text { Integrated infrastructure and } \\
\text { security }\end{array}$ & & \\
\hline Standardization & & \\
\hline API security & & \\
\hline Strong customer authentication & & \\
\hline Fraud detection & \multirow{3}{*}{$\begin{array}{l}\text { Applying optimization } \\
\text { and correlation } \\
\text { techniques }\end{array}$} & \\
\hline Predictive analysis & & \\
\hline Prescriptive analysis & & \\
\hline Market making and marketing & \multirow[t]{2}{*}{ Market dynamics } & \\
\hline Business insights & & \\
\hline Weaknesses & \multirow[t]{2}{*}{ Internal analysis } & \multirow{7}{*}{$\begin{array}{c}\text { digital strategic management } \\
\text { of customer }\end{array}$} \\
\hline Strengths & & \\
\hline Opportunities & \multirow[b]{2}{*}{ External analysis } & \\
\hline Inhibitors & & \\
\hline Strategic look and horizon & Strategic thinking & \\
\hline Smart data & Customer data & \\
\hline Social media & Social media & \\
\hline \multicolumn{3}{|l|}{ Customer-centric } \\
\hline Quality & \multirow[t]{2}{*}{ Customer orientation } & \multirow{4}{*}{$\begin{array}{c}\text { Customer experience } \\
\text { management }\end{array}$} \\
\hline Customer consent management & & \\
\hline $\begin{array}{l}\text { Implementation of customer } \\
\text { experience }\end{array}$ & \multirow{2}{*}{ Customer experience } & \\
\hline Optimizing the customer & & \\
\hline
\end{tabular}


REVISTA DE LA UNIVERSIDAD DEL ZULIA. 3época. Año 12 N 32, 2021

Mohammad Bagher Arayesh et al. /// Thematic analysis on a model of implementation of open ... 414-443

DOI: http://dx.doi.org/10.46925//rdluz.32.25

\begin{tabular}{|c|c|c|}
\hline experience & management & \\
\hline $\begin{array}{l}\text { Homogenization of Customer } \\
\text { Experience }\end{array}$ & & \\
\hline $\begin{array}{c}\text { Software and technology } \\
\text { infrastructures }\end{array}$ & Providing software & \multirow{7}{*}{$\begin{array}{c}\text { Infrastructure engineering } \\
\text { and implementation } \\
\text { mechanisms }\end{array}$} \\
\hline $\begin{array}{l}\text { Mechanism and Modern System } \\
\text { Architecture }\end{array}$ & $\begin{array}{l}\text { infrastructure and } \\
\text { system architecture }\end{array}$ & \\
\hline Platform design & & \\
\hline Pre-implementation mechanisms & \multirow{3}{*}{$\begin{array}{l}\text { Implementation } \\
\text { mechanisms }\end{array}$} & \\
\hline $\begin{array}{l}\text { Current implementation } \\
\text { mechanisms }\end{array}$ & & \\
\hline $\begin{array}{l}\text { Post-implementation } \\
\text { mechanisms }\end{array}$ & & \\
\hline Successful implementation & $\begin{array}{c}\text { Successful } \\
\text { implementation }\end{array}$ & \\
\hline Comprehensive business model & New business modeling & \multirow{8}{*}{$\begin{array}{l}\text { structural productivity and } \\
\text { digital governance in the } \\
\text { shadow of knowledge } \\
\text { partnerships }\end{array}$} \\
\hline New businesses & & \\
\hline Digital leadership & Digital leadership & \\
\hline $\begin{array}{l}\text { Agility in competition and } \\
\text { profitability }\end{array}$ & Competitiveness & \\
\hline $\begin{array}{l}\text { Banking culture with other } \\
\text { partners }\end{array}$ & $\begin{array}{l}\text { Development of } \\
\text { technical - cultural } \\
\text { relations }\end{array}$ & \\
\hline Downsizing banking processes & Structural efficiency & \\
\hline $\begin{array}{c}\text { Creating a new digital value } \\
\text { chain }\end{array}$ & value creation & \\
\hline $\begin{array}{l}\text { Multiple value creation of } \\
\text { customer }\end{array}$ & & \\
\hline
\end{tabular}

Source: Research findings

Table 4 shows the frequency of the basic themes 
REVISTA DE LA UNIVERSIDAD DEL ZULIA. $3^{a}$ época. Año 12 N $^{\circ} 32,2021$

Mohammad Bagher Arayesh et al. /// Thematic analysis on a model of implementation of open ... 414-443

DOI: http://dx.doi.org/10.46925//rdluz.32.25

Table 4. Frequency of repetition of basic themes

\begin{tabular}{|c|c|c|c|}
\hline Basic themes & Frequency & Basic themes & Frequency \\
\hline $\begin{array}{l}\text { Banking flexibility and } \\
\text { compatibility }\end{array}$ & 12 & Customer orientation & 19 \\
\hline Participatory culture & 10 & $\begin{array}{c}\text { Customer experience } \\
\text { management }\end{array}$ & 25 \\
\hline Managing payment channels & 12 & $\begin{array}{c}\text { Providing software } \\
\text { infrastructure and system } \\
\text { architecture }\end{array}$ & 8 \\
\hline Risk management & 9 & $\begin{array}{l}\text { Implementation } \\
\text { mechanisms }\end{array}$ & 15 \\
\hline Cost-benefit evaluation & 12 & Successful implementation & 12 \\
\hline Activity framing & 15 & New business modeling & 12 \\
\hline Legal requirements & 14 & Digital leadership & 9 \\
\hline $\begin{array}{l}\text { Applying optimization and } \\
\text { correlation techniques }\end{array}$ & 7 & Competitiveness & 9 \\
\hline Market dynamics & 12 & $\begin{array}{l}\text { Development of technical - } \\
\text { cultural relations }\end{array}$ & 5 \\
\hline Internal analysis & 10 & Structural efficiency & 12 \\
\hline External analysis & 8 & value creation & 9 \\
\hline Strategic thinking & 15 & & \\
\hline Customer data & 12 & Social media & 10 \\
\hline
\end{tabular}

Source: Research findings

In the fourth step, the researcher chose inclusive themes, by applying sensory constructs and technical terms derived from the theoretical and specialized background of 
REVISTA DE LA UNIVERSIDAD DEL ZULIA. 3a época. Año 12 Nº 32, 2021

Mohammad Bagher Arayesh et al. /// Thematic analysis on a model of implementation of open ... 414-443

DOI: http://dx.doi.org/10.46925//rdluz.32.25

the and according to the interviewees' point of view and linked to relevant categories systematically. When the theoretical adequacy is reached, the core of open banking implementation was formed in the conditions of commercial banks of Iran, encompassing the themes of Economic Management and Banking Process Reform, structural productivity and digital governance in the shadow of knowledge partnerships, Customer experience management and digital strategic management of the customer. In step 5, a thematic network was drawn to facilitate the visualization of the themes and the meaning of the idea (Attride - Stirling, 2001). In this step, while examining the consistency of the themes with the extracted codes and sorting themes, the basic, organizing inclusive themes were outlined. Accordingly, in figure 2, the final model of research is presented in the context of the thematic network.

The results of the descriptive analysis of the field interviews and their coding showed that organizer themes, "structural productivity and digital governance in the shadow of knowledge partnerships" with 56 repeats have been of the utmost importance among all organizing themes of the open banking implementation model. This theme includes the basic themes of new business modeling, digital leadership, competitiveness, development of technical - cultural relations, structural efficiency and value creation.

The second main theme, with the most repetition, was " digital strategic management of customer ", which is mentioned in 55 cases. This theme has included subthemes of internal analysis, external analysis, strategic thinking, customer data, and social media. "economic management and banking process reform" was the third major theme respondents mentioned 47 times. It includes the sub-themes of flexibility and adaptability of banks, collaborative culture, payment channel management, risk management, and costbenefit assessment. The fourth main theme is "customer experience management" that the interviewees mentioned 44 times during the interviews. This theme has included the themes of customer orientation, customer experience management. 
REVISTA DE LA UNIVERSIDAD DEL ZULIA. $3^{a}$ época. Año 12 N $^{\circ} 32,2021$

Mohammad Bagher Arayesh et al. /// Thematic analysis on a model of implementation of open ... 414-443

DOI: http://dx.doi.org/10.46925//rdluz.32.25

Activity framing, Legal requirements,

Applying optimization and

correlation techniques

Technical-legal compatibility

based on market and technology

optimization activities

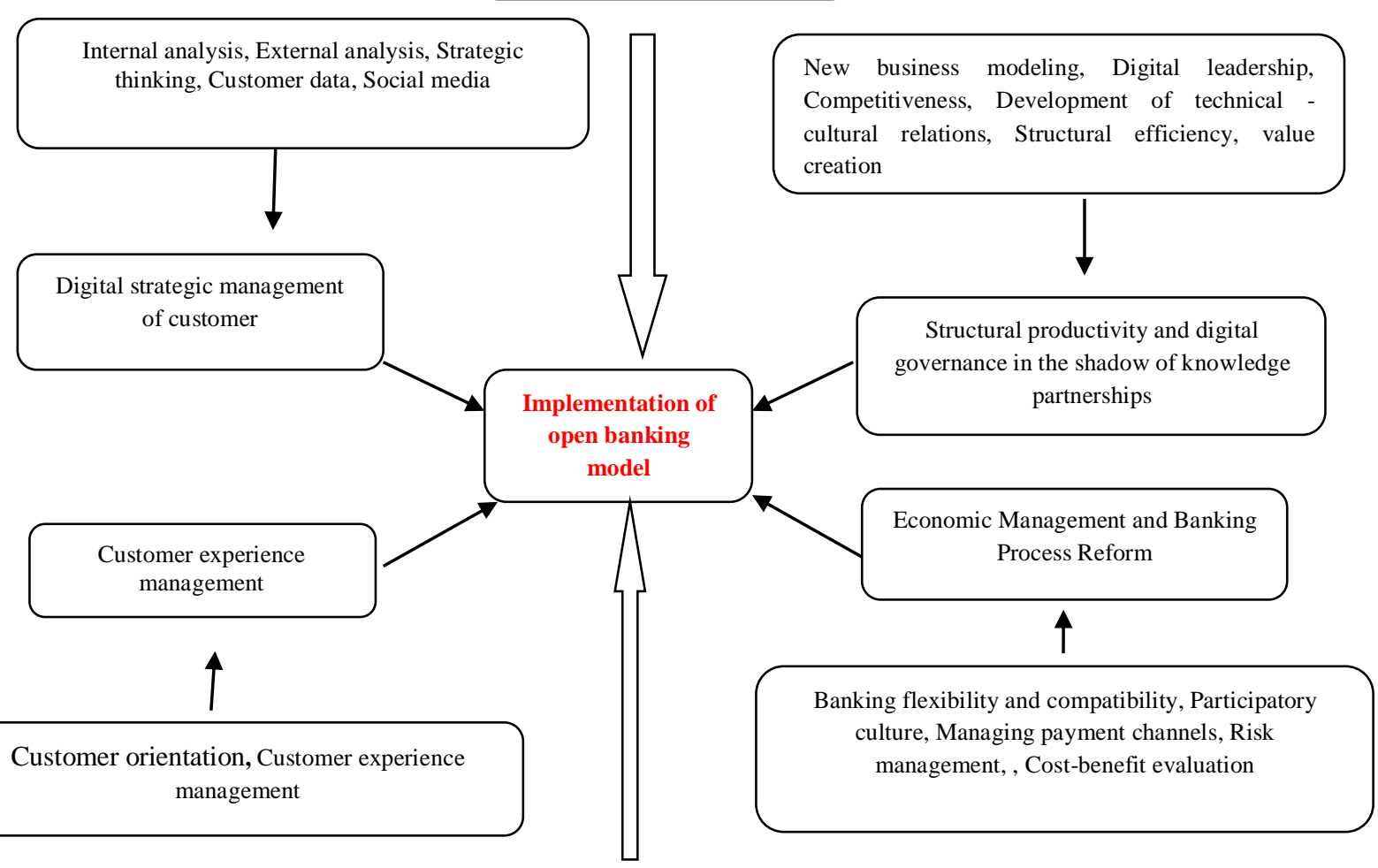

Infrastructure engineering and

implementation mechanisms

$\uparrow$

Software and technology infrastructures, Mechanism and Modern System

Architecture, Platform design, Pre-implementation mechanisms, Current

implementation mechanisms, Post-implementation mechanisms, Post-

implementation mechanisms, Successful implementation,

Figure 2. The final thematic research model 
REVISTA DE LA UNIVERSIDAD DEL ZULIA. $3^{a}$ época. Año 12 N$^{\circ} 32,2021$

Mohammad Bagher Arayesh et al. /// Thematic analysis on a model of implementation of open ... 414-443

DOI: http://dx.doi.org/10.46925//rdluz.32.25

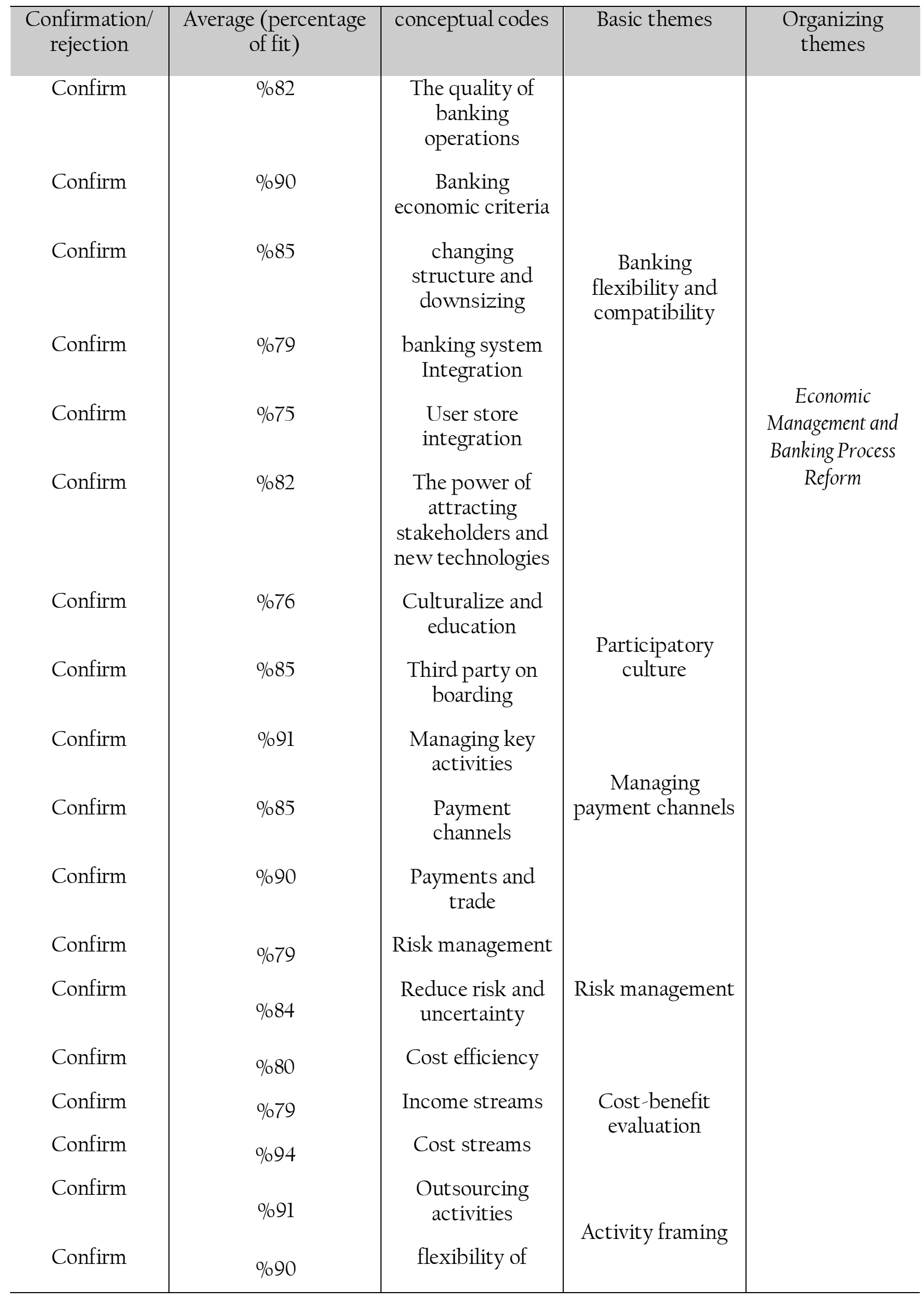


REVISTA DE LA UNIVERSIDAD DEL ZULIA. 3a época. Año 12 Nº 32, 2021

Mohammad Bagher Arayesh et al. /// Thematic analysis on a model of implementation of open ... 414-443

DOI: http://dx.doi.org/10.46925//rdluz.32.25

\begin{tabular}{|c|c|c|c|c|}
\hline Confirm & $\% 88$ & $\begin{array}{l}\text { organizational } \\
\text { platform } \\
\text { Architecture } \\
\text { management and } \\
\text { API monitoring }\end{array}$ & & \\
\hline Confirm & $\% 85$ & API specification & & \\
\hline Confirm & $\% 80$ & $\begin{array}{l}\text { Motivation and } \\
\text { loyalty programs }\end{array}$ & & \\
\hline Confirm & $\% 78$ & $\begin{array}{c}\text { Regulatory and } \\
\text { legal } \\
\text { infrastructure }\end{array}$ & & $\begin{array}{l}\text { Technical-legal } \\
\text { compatibility } \\
\text { based on market } \\
\text { and technology }\end{array}$ \\
\hline Confirm & $\% 80$ & $\begin{array}{l}\text { Integrated } \\
\text { infrastructure } \\
\text { and security }\end{array}$ & $\begin{array}{l}\text { Legal } \\
\text { requirements }\end{array}$ & $\begin{array}{l}\text { optimization } \\
\text { activities }\end{array}$ \\
\hline Confirm & $\% 83$ & Standardization & & \\
\hline Confirm & $\% 87$ & API security & & \\
\hline Confirm & $\% 86$ & $\begin{array}{l}\text { Strong customer } \\
\text { authentication }\end{array}$ & & \\
\hline Confirm & $\% 87$ & Fraud detection & $\begin{array}{c}\text { Applying } \\
\text { optimization and }\end{array}$ & \\
\hline Confirm & $\% 91$ & $\begin{array}{c}\text { Predictive } \\
\text { analysis }\end{array}$ & $\begin{array}{l}\text { correlation } \\
\text { techniques }\end{array}$ & \\
\hline Confirm & $\% 81$ & $\begin{array}{l}\text { Prescriptive } \\
\text { analysis }\end{array}$ & & \\
\hline Confirm & $\% 85$ & $\begin{array}{l}\text { Market making } \\
\text { and marketing }\end{array}$ & Market dynamics & \\
\hline Confirm & $\% 83$ & Business insights & & \\
\hline Confirm & $\% 78$ & Weaknesses & Internal analysis & \\
\hline Confirm & $\% 87$ & Strengths & & \\
\hline Confirm & $\% 82$ & Opportunities & External analysis & $\begin{array}{l}\text { digital strategic } \\
\text { management of }\end{array}$ \\
\hline Confirm & $\% 81$ & Inhibitors & & customer \\
\hline Confirm & $\% 85$ & $\begin{array}{l}\text { Strategic look } \\
\text { and horizon }\end{array}$ & $\begin{array}{l}\text { Strategic } \\
\text { thinking }\end{array}$ & \\
\hline Confirm & $\% 90$ & Smart data & Customer data & \\
\hline Confirm & $\% 85$ & Social media & Social media & \\
\hline
\end{tabular}


REVISTA DE LA UNIVERSIDAD DEL ZULIA. $3^{a}$ época. Año 12 N $^{\circ} 32,2021$

Mohammad Bagher Arayesh et al. /// Thematic analysis on a model of implementation of open ... 414-443

DOI: http://dx.doi.org/10.46925//rdluz.32.25

\begin{tabular}{|c|c|c|c|c|}
\hline Confirm & $\% 87$ & Customer-centric & & \\
\hline Confirm & $\% 96$ & Quality & Customer & \\
\hline Confirm & $\% 84$ & $\begin{array}{c}\text { Customer } \\
\text { consent } \\
\text { management }\end{array}$ & orientation & $\begin{array}{l}\text { Customer } \\
\text { experience }\end{array}$ \\
\hline Confirm & $\% 94$ & $\begin{array}{l}\text { Implementation } \\
\text { of customer } \\
\text { experience }\end{array}$ & $\begin{array}{l}\text { Customer } \\
\text { experience }\end{array}$ & management \\
\hline Confirm & $\% 91$ & $\begin{array}{l}\text { Optimizing the } \\
\text { customer } \\
\text { experience }\end{array}$ & management & \\
\hline Confirm & $\% 90$ & $\begin{array}{l}\text { Homogenization } \\
\text { of Customer } \\
\text { Experience }\end{array}$ & & \\
\hline Confirm & $\% 80$ & $\begin{array}{l}\text { Software and } \\
\text { technology } \\
\text { infrastructures }\end{array}$ & $\begin{array}{c}\text { Providing } \\
\text { software } \\
\text { infrastructure }\end{array}$ & \\
\hline Confirm & $\% 90$ & $\begin{array}{l}\text { Mechanism and } \\
\text { Modern System } \\
\text { Architecture }\end{array}$ & $\begin{array}{l}\text { and system } \\
\text { architecture }\end{array}$ & \\
\hline Confirm & $\% 87$ & Platform design & & $\begin{array}{l}\text { Infrastructure } \\
\text { engineering and }\end{array}$ \\
\hline Confirm & $\% 86$ & $\begin{array}{c}\text { Pre- } \\
\text { implementation } \\
\text { mechanisms }\end{array}$ & $\begin{array}{l}\text { Implementation } \\
\text { mechanisms }\end{array}$ & $\begin{array}{l}\text { implementation } \\
\text { mechanisms }\end{array}$ \\
\hline Confirm & $\% 82$ & $\begin{array}{c}\text { Current } \\
\text { implementation } \\
\text { mechanisms }\end{array}$ & & \\
\hline Confirm & $\% 78$ & $\begin{array}{l}\text { Post- } \\
\text { implementation } \\
\text { mechanisms }\end{array}$ & & \\
\hline Confirm & $\% 80$ & $\begin{array}{c}\text { Successful } \\
\text { implementation }\end{array}$ & $\begin{array}{c}\text { Successful } \\
\text { implementation }\end{array}$ & \\
\hline Confirm & $\% 89$ & $\begin{array}{l}\text { Comprehensive } \\
\text { business model }\end{array}$ & $\begin{array}{l}\text { New business } \\
\text { modeling }\end{array}$ & \\
\hline Confirm & $\% 90$ & New businesses & & \\
\hline Confirm & $\% 90$ & Digital leadership & Digital leadership & structural \\
\hline Confirm & $\% 88$ & $\begin{array}{c}\text { Agility in } \\
\text { competition and }\end{array}$ & Competitiveness & $\begin{array}{l}\text { productivity and } \\
\text { digital }\end{array}$ \\
\hline
\end{tabular}


REVISTA DE LA UNIVERSIDAD DEL ZULIA. 3época. Año 12 N 32, 2021

Mohammad Bagher Arayesh et al. /// Thematic analysis on a model of implementation of open ... 414-443

DOI: http://dx.doi.org/10.46925//rdluz.32.25

\begin{tabular}{|c|c|c|c|c|}
\hline Confirm & $\% 87$ & $\begin{array}{l}\text { profitability } \\
\text { Banking culture } \\
\text { with other } \\
\text { partners }\end{array}$ & $\begin{array}{l}\text { Development of } \\
\text { technical - } \\
\text { cultural relations }\end{array}$ & $\begin{array}{l}\text { governance in } \\
\text { the shadow of } \\
\text { knowledge } \\
\text { partnerships }\end{array}$ \\
\hline Confirm & $\% 81$ & $\begin{array}{l}\text { Downsizing } \\
\text { banking } \\
\text { processes }\end{array}$ & $\begin{array}{l}\text { Structural } \\
\text { efficiency }\end{array}$ & \\
\hline Confirm & $\% 88$ & $\begin{array}{l}\text { Creating a new } \\
\text { digital value } \\
\text { chain }\end{array}$ & value creation & \\
\hline Confirm & $\% 92$ & $\begin{array}{l}\text { Multiple value } \\
\text { creation of } \\
\text { customer }\end{array}$ & & \\
\hline
\end{tabular}

Table 5. Matching basic themes with organizer themes

Source: Research findings

\subsection{Model validation}

After designing the model based on the results of the interviews, this model was represented to 4 academic experts in a model validation questionnaire to obtain their views on the relevance of basic concepts to organizational themes. Construct validity was used to validate the model. If approved by $75 \%$ of experts, the model is valid (Taherdoost, 2016). The SPSS software was used to calculate the mean of expert opinions to determine whether or not themes fit. Table 5 shows the fit of the basic themes to the organizer themes.

The model obtained from the interviews was confirmed as the final model of the research according to the model validity table and the views of academic experts.

\section{Conclusion and Recommendations}

Open banking, along with its inherent features in the banking system, is a trend that will shape the future of the banking industry. Open banking is a digital transformation of the banking business model in which the banking business model moves from subsidiary income to a new share of non-equity and payroll income. In addition to transforming the banking business, it is done adaptation to the Framework of Government. Modern banking has opened a new position in the economic system by leveraging technology, which banks 
REVISTA DE LA UNIVERSIDAD DEL ZULIA. 3a época. Año 12 Nº 32, 2021

Mohammad Bagher Arayesh et al. /// Thematic analysis on a model of implementation of open ... 414-443

DOI: http://dx.doi.org/10.46925//rdluz.32.25

are not only key players. The banking system's customer expectations have changed along with technology.

They expect to be able to receive different services consistent with day-to-day user experiences. Traditional banks are not necessarily the best way to serve these customers, and new players will enter the monetary system with a better understanding of the needs of users and customers. on the other hand, banks as traditional actors of the system, have been able to gain deep trust in their customers over the years, and so they are considered a safer place to get paid services. The convergence of new and traditional actors in this ecosystem can create the best return for monetary customers, as well as leading to customer confidence and tailoring new banking services to their needs.

In the banking ecosystem, the architecture of banking systems is different from traditional ways, and by using open banking platforms, it provides synergy between banks and new players. In open banking, not only new players are found to play key roles in the monetary system, but also the provision of banks' software and hardware infrastructures will also be shifted to a three-way specialized approach bank, supplier and dedicated executor. Providers produce and support the core of comprehensive banking solutions. Dedicated executives have the task of adapting the bank's internal needs to the core of comprehensive banking solutions and implement new bank products on these platforms.

This study was presented with a conceptual model for the implementation of an open banking model in the situation of Iranian commercial banks using grounded theory. The process of information analysis in data-the derived theory is based on the three stages of open coding (creation of concepts and categories), axial coding (axial category identification, causal conditions, the interveners, contexts, strategies, and consequences) and selective coding (theory creation). In the open coding phase, 60 conceptual codes and 25 main categories were identified after extracting and coding all the key points of the interviews.

In the axial coding process, the categories derived from the open coding process were categorized into six categories including customer experience management, economic management and banking process reform, digital data management strategic of customer, technical-legal compatibility based on market and technology optimization activities, infrastructure engineering and implementation mechanisms, and structural productivity 
REVISTA DE LA UNIVERSIDAD DEL ZULIA. 3a época. Año 12 Nº 32, 2021

Mohammad Bagher Arayesh et al. /// Thematic analysis on a model of implementation of open ... 414-443

DOI: http://dx.doi.org/10.46925//rdluz.32.25

and digital governance in the shadow of competing knowledge partners. Table 6 compares the elements and components of the model with the empirical and theoretical literature of the research subject. The comparative action in this section can show the innovations presented in this study and reflect the "content" or "localization framework" of the research results as well as the extent of its participation in the theoretical foundations of the subject.

One of the main goals of this study was to thematic analysis on a model of implementation of open and technological banking in commercial banks in Iran. So that banking activists can continue to live in the competitive world of today's business and the sustainability requirements in this space. For this purpose, some suggestions are presented concerning the results of this study.

- According to the fundamental nature of the present study, it is recommended that future researchers evaluate each part of the proposed model in terms of quantitative and applied studies. The basic dimensions and components introduced in the present study provide the opportunity for independent studies along with detailed explanations and analyzes to provide practical and practical solutions for the complete and comprehensive deployment of an open banking system in the country's economy.

- Policies adopted by the government of regulators affect the performance of all actors in the open banking ecosystem. Therefore, policymakers and regulators can facilitate open banking in the country by providing rules and standards. The result of regulator policies and guidelines can reduce credit risk and strengthen the accreditation system, along with the rational participation of each ecosystem member.

- Providing a conceptual framework for open banking implementation is needed to guide actions and efforts properly. This conceptual framework is presented in this study.

- It is recommended for bank managers to first consider the necessity of establishing open banking in their banks, based on the developed framework and the results of the accreditation process because if the necessity of deployment is not understood, the deployment of open banking, like other management approaches, will become a managerial fashion and after a while, its importance diminishes.

- After understanding the requirements of establishing open banking, bank managers will be assured that they have the platforms and requirements needed to deploy it. This 
REVISTA DE LA UNIVERSIDAD DEL ZULIA. 3época. Año 12 N 32, 2021

Mohammad Bagher Arayesh et al. /// Thematic analysis on a model of implementation of open ... 414-443

DOI: http://dx.doi.org/10.46925//rdluz.32.25

will help them to meet fewer obstacles before, during and after the establishment of open banking.

Table 6. Comparison of model components with experimental and theoretical literature of research subject

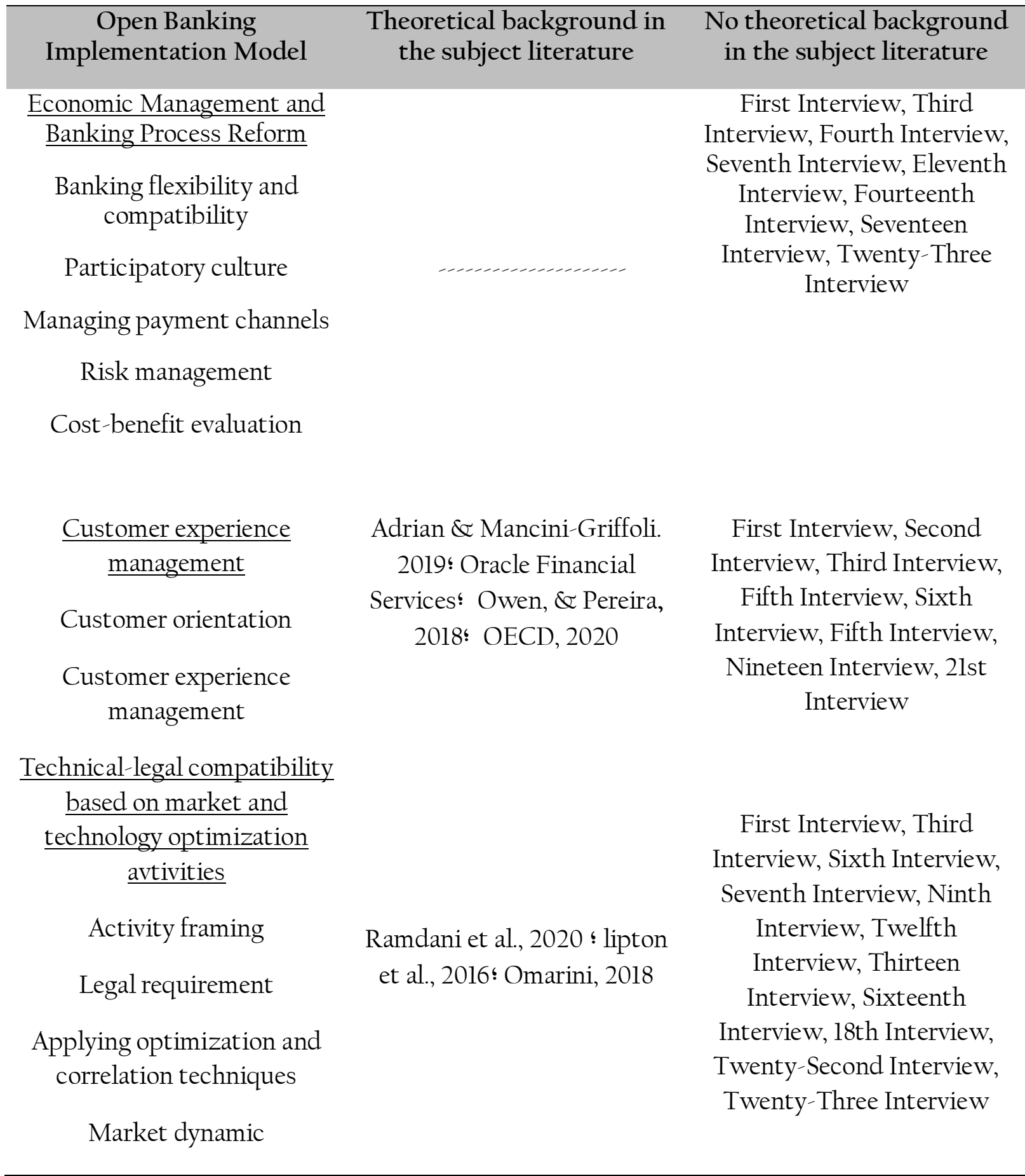


REVISTA DE LA UNIVERSIDAD DEL ZULIA. $3^{a}$ época. Año 12 N$^{\circ} 32,2021$

Mohammad Bagher Arayesh et al. /// Thematic analysis on a model of implementation of open ... 414-443

DOI: http://dx.doi.org/10.46925//rdluz.32.25

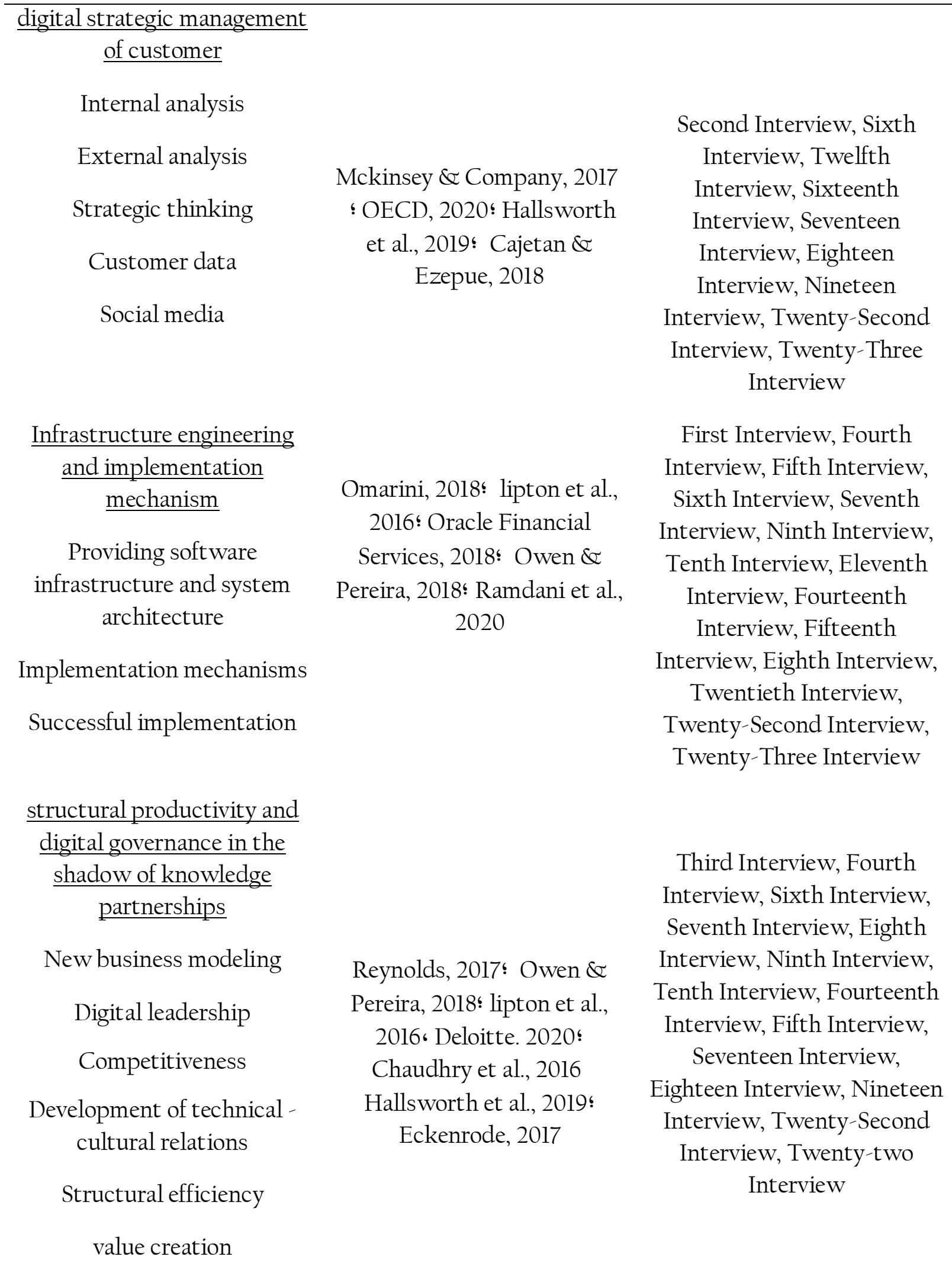


REVISTA DE LA UNIVERSIDAD DEL ZULIA. $3^{a}$ época. Año 12 N$^{\circ} 32,2021$

Mohammad Bagher Arayesh et al. /// Thematic analysis on a model of implementation of open ... 414-443

DOI: http://dx.doi.org/10.46925//rdluz.32.25

\section{References}

Accenture (2018). Accenture Open Banking for Businesses Survey 2018: It'S now open banking. https://www.accenture.com/_acnmedia/PDF-90/Accenture-Open-BankingBusinesses-Survey.pdf. [accessed on 10. 04. 2020].

Adrian T., Mancini-Griffoli T. 2019. The rise of digital money. FinTech Note 19/01, Int. Monet. Fund, Washington, DC. https:/www.imf.org/en/Publications/fintechnotes/Issues/2019/07/12/The-Rise-of-Digital-Money-47097. [accessed on 08. 03. 2020].

Alhojailan, M I. (2012). Thematic Analysis: A critical review of its process and evaluation. West East Journal of Social Sciences, 1(1): 39-47.

Berger, A N., Molyneux, P., \& Wilson, j o. (2012). Banking an Overview: The Oxford Handbook of Banking. https://www.oxfordhandbooks.com/view/10.1093/oxfordhb/9780199640935.001.0001/oxfor dhb-9780199640935-e-001. [accessed on 08. 03. 2020]. DOI: 10.1093/oxfordhb/9780199640935.013.0001.

Asadollah, M., Sanavifard, R., \& Hamidizadeh, A. Introducing a New E-Banking Model Based on the Rise of FinTechs and Startups (A Case of a Private Bank In Iran). Journal of Technology Development, 2019, 7(2): 195-248. https://doi.org/10.22104/JTDM.2019.3508.2214. (In Persian).

Attride-Striling, J. (2001). Thematic network. An analytic tool for qualitative research. Journal of Qualitative Research, 1(3): 285-405.

Barquin, S., Vinayamak, H. V., \& Heidi, Y. (2015). Digital banking in ASEAN:Increasing consumer sophistication and openness. McKinsey \& Company. https://www.mckinsey.com//media/mckinsey/businessng. [accessed on 24. 08. 2018].

Braun, V., \& Clark, V. (2006). Using thematic analysis in psychology. Qualitative Reseach in Psychology, 2006, 3(2): 77-101.

Brodsky, L. and Oakes, L. (2017). Data sharing and open banking. McKinsey \& Company. https://www.mckinsey.com/industries/financial-services/our-insights/data-sharing-andopen-banking [accessed on 03. 08. 2018].

Camerinelli, E. (2017). Open Bank, APIs, and Financial Services Ecosystems: The Future of Banking. http://softwareag.com, $\odot 2017$ Aite Group LLC, 2017. [accessed on 24. 08. 2018].

Chaudhry, A A., Parveiz, A., \& Javed, Y. (2016). Determinants of Users Trust for Branchless Banking in Pakistan. Journal of Internet Banking and Commerce, 21(1): 1-15.

Dargahi, E.; Tahriri, A. Representing a Model for Implementing International Financial Reporting Standards in Iran, Revista de la Universidad del Zulia, ll (31), 141-159. DOI: http://dx.doi.org/10.46925//rdluz.31.11 
REVISTA DE LA UNIVERSIDAD DEL ZULIA. 3a época. Año 12 Nº 32, 2021

Mohammad Bagher Arayesh et al. /// Thematic analysis on a model of implementation of open ... 414-443

DOI: http://dx.doi.org/10.46925//rdluz.32.25

Deloitte. (2020). Banking on the Future. https://www2.deloitte.com/content/dam/Deloitte/in/Documents/financial-services/in-fsdeloitte-banking-colloquium-thoughtpaper-cii.pdf.[accessed on 02. 06. 2020].

Deloitte. (2019). Creating an open banking framework for Canada: https://www2.deloitte.com/content/dam/Deloitte/ca/. [accessed on 09. 07. 2019].

Deloitte. (2015). How to flourish in an uncertain future of open banking. https://www2.deloitte.com/content/dam/Deloitte/uk/Documents/financial-

services/deloitte-uk-open-banking-how-to-flourish-in-an-uncertain-future.pdf. [accessed on 11. 05. 2019].

Deloitte. (2014). Banking disrupted how technology is threatening traditional european retail banking model. https://www./dttl-fsi-uk-Banking-Disrupted-2014-06.pdf [accessed on 12. 11. 2019].

Eckenrode, J. (2017). Talent, technology, and transformation: Global executives' expectations for the future of financial services. https://www2.deloitte.com/content/dam/Deloitte/de/Documents/financial-services/talenttechnology-transformation.pdf. [accessed on 18.10. 2019].

Euro Banking Association. (2017). Open Banking: advancing customer-centricity Analysis and overview.

https://www.abe-

eba.eu/media/azure/production/1355/eba_open_banking_advancing_customer-

centricity_march_2017.pdf. [accessed on 02.06. 2019].

Fingleton. (2019). Open banking, preparing for lift off. https://www.openbanking.org.uk/wpcontent/uploads/open-banking-report-150719.pdf. [accessed on 25. 07. 2019].

Cajetan, I. M., \& Ezepue, P. O. Digital banking, customer, experience and bank financial performance. International Journal of Bank marketing, 2018, 36(2): 230-256.

Hallsworth, J., Pollari, I., \& Ruark, R. (2019). Open banking opens greater value. https://assets.kpmg/content/dam/kpmg/xx/pdf/2019/05/open-banking-opening-

opportunities-for-customer-value.pdf. [accessed on 02. 06. 2020].

Lipton, A., Shrier, D., \& Pentland, A. (2016). Digital Banking Manifesto: The End of Banks?. Connection Science \& Engineering, Massachusetts Institute of Technology. https://www.getsmarter.com/blog/wp - content/uploads/2017/07/mit_report.pdf. [accessed on 25. 07. 2019].

Mckinsey \& Company. (2017). Customer experience: New capabilities, new audiences, new opportunities.

https://www.mckinsey.de//media/mckinsey/industries/public\%20and\%20social\%20sector /our\%20insights/cx\%20compendium\%202017/customer-experience-compendium-july2017.pdf. [accessed on 02. 06. 2018]. 
REVISTA DE LA UNIVERSIDAD DEL ZULIA. $3^{a}$ época. Año 12 N$^{\circ} 32,2021$

Mohammad Bagher Arayesh et al. /// Thematic analysis on a model of implementation of open ... 414-443

DOI: http://dx.doi.org/10.46925//rdluz.32.25

OECD (2020), Digital Disruption in Banking and its Impact on Competition http://www.oecd.org/daf/competition/digital-disruption-in-financial-markets.htm [accessed on 05. 02. 2020].

Omarini, A. (2018). Banks and Fintechs: How to Develop a Digital Open Banking Approach for the Bank's Future. International Business Research, 11(9): 23-36, https://doi.org/10.5539/ibr.vlln9p23.

Oracle Financial Services. (2018). The New Digital Demand in Retail Banking: From Customer Experience to Engagement Across Life Moments. https://www.digitalnewsasia.com/sites/default/files/PDF/New\%20Digital\%20Demand\%20 Report\%202018.pdf. [accessed on 18. 07. 2020].

Owen, A L., \& Pereira, J M. (2018). Bank concentration, Competition and financila inclusion. Review of Development Finance, 8(1): 1-17, https://doi.org/10.1016/j.rdf.2018.05.001.

Ramdani, B., Rothwell, B., and Boukrami, E. (2020). Open banking: the emergene of new digital business model. International Journal of Innovation and Technology Management, 17(5), https://doi.org/10.1142/S0219877020500339.

Reynolds, F. (2017). Open Banking: A Consumer Perspective. https://www.openbanking.org.uk/wp-content/uploads/Open-Banking-A-ConsumerPerspective.pdf. [accessed on 15. 06. 2020].

Taherdoost, H. (2016). Validity and Reliability of the Research Instrument; How to Test the Validation of a Questionnaire/Survey in a Research. International Journal of Academic Research in Management, 593): 28-36.

Vaezi, R., Chekin, M., \& Aslipour, H. (2018). Policy-making challenges in the field of health tourism in Iran. Tourism Management Studies, 13(41): 1-40, 10.22054/TMS.2018.19752.1548. ( In Persian). 